\title{
Recommendations for the provision of palliative care to people
} with COVID-19

\author{
Jorge A. Ramos-Guerrero, * Ramiro López-Elizalde, Leticia Asencio-Huertas, Carlos Enríquez-López, \\ Judith García de Alba-Verduzco, Oscar Flores-Munguía, Luis Hernández-Flores, Alberto León-Alatorre, \\ Miguel Nakamura-López, Iris Narváez-Sarmiento, Juan Reyes-Torres, Patricia Ornelas-Tavares, \\ Livier Ortiz-Coronado, Mónica Osio-Saldaña, Nayely Salazar-Trujillo, Alejandro Quiroz-Hernández, \\ Dalia Vásquez-Vásquez and Bernardo Villa-Cornejo \\ Palliative Care Institutional Program, Instituto de Seguridad y Servicios Sociales de los Trabajadores del Estado, Mexico City, Mexico
}

\begin{abstract}
The pandemic of SARS-CoV-2 infection, which causes COVID-19, has deeply affected health systems and has had a significant impact on families, communities and nations. A comprehensive response strategy requires, in addition to epidemiological, scientific and technical considerations, for human suffering associated with disease, vulnerability and death not to be forgotten. Palliative care for people with suspicion or diagnosis of COVID-19 with serious evolution, and their families should also be a key part of organized actions that help alleviate suffering and improve quality of life by controlling symptoms, addressing psychological, emotional, social and spiritual needs, support for advanced care planning and its goals, end-of-life care, as well as support in complex decision-making and ethical problems, among others. Recommendations are provided for offering palliative care in COVID-19 pandemic context.
\end{abstract}

KEY WORDS: COVID-19. Pandemic. Palliative care. Quality of life.

\section{Recomendaciones para la provisión de atención paliativa a personas con COVID-19}

\section{Resumen}

La pandemia de infección por SARS-CoV-2, la cual es causada por COVID-19, ha afectado profundamente a los sistemas de salud y ha ocasionado un enorme impacto en las familias, las comunidades y las naciones. La estrategia de respuesta integral requiere que además de las consideraciones epidemiológicas, científicas y técnicas, no se olvide el sufrimiento humano asociado a la enfermedad, la vulnerabilidad y la muerte. La atención paliativa a personas con sospecha o diagnóstico de COVID-19 con evolución grave y sus familias debe ser también parte clave de la acción organizada que ayude al alivio del sufrimiento y mejore la calidad de vida mediante el control de los síntomas, el abordaje de las necesidades psicológicas, sociales y espirituales, el apoyo para la planificación de la atención avanzada y la articulación de los objetivos de la misma, el cuidado de la persona en la fase final de la vida, así como el soporte ante la toma de decisiones complejas y problemas éticos, entre otros. Se ofrecen recomendaciones para brindar los cuidados paliativos en el contexto de la pandemia de COVID-19.

PALABRAS CLAVE: COVID-19. Pandemia. Cuidados paliativos. Calidad de vida.

\footnotetext{
Correspondence:

Date of reception: $25-09-2020$

*Jorge A. Ramos-Guerrero

Date of acceptance: $08-12-2020$

E-mail: paliativospediatricosmx@gmail.com

DOI:10.24875/GMM.M21000587

Gac Med Mex. 2021;157:436-442

Contents available at PubMed license (http://creativecommons.org/licenses/by-nc-nd/4.0/).
} 


\section{Introduction}

In December 2019, cases of pneumonia appeared in China that were caused by SARS-CoV-2 (as later was documented), which is a new coronavirus that causes coronavirus disease-2019 (COVID-19). On March 11, 2020, the World Health Organization declared this disease a global pandemic. By October 12, 2021, 236,599,025 cases of COVID-19 and 4,831,486 deaths had been reported in the world, with a case fatality rate of $2 \%$. In Mexico, 3,732,429 cases and 282,773 deaths had been confirmed'.

This health emergency, like a tsunami, has deeply affected health systems, generating an enormous impact on nations, communities, families and individuals ${ }^{2}$; in turn, it has become a powerful suffering amplifier, which is why "alleviation of the burden of pain and severe distress associated with life-threatening or life-limiting health conditions, as well as with end of life itself" is imperative ${ }^{3}$.

The World Health Organization establishes the recommendation to "provide access to palliative care for COVID-19, paying special attention to the protection of people with preexisting health conditions, the elderly and other people at risk." Failure to provide palliative care in these settings would exacerbate the tragedy of the pandemic and might be considered a factor of medical care failure ${ }^{4-8}$.

\section{Palliative care during COVID-19}

Palliative care includes "active and holistic care for people of all ages who experience serious health-related suffering due to severe illness, and especially for those near the end of life. Its purpose is to improve the quality of life of patients, their families and their caregivers" $"$. In current context, they should be provided to people with life-threatening or life-limiting conditions other than COVID-19 (preexisting or newly-onset conditions), with severe acute respiratory infection (SARI), with suspected or confirmed COVID-19, in particular to people who are not provided advanced life support for any reason or with severe illness with severe symptoms, as well as those who progress to the final phase of life.

Active care should be provided and kept available for the control of patient symptoms, comprehensive approach to the psychological, emotional, social and spiritual needs; advance planning of care, support in complex decision-making, as well as support to families through assertive communication and management of uncertainty in the face of the disease. It is necessary for actions that allow palliative care to be granted to those who require it to be coordinated ${ }^{3,4,6,10-12}$.

\section{Symptom control in the patient with severe COVID-19}

Many patients can rapidly deteriorate and experience severe symptoms, which is why having a concise and rapid strategy for their management is necessary $8,10-14$.

- Dyspnea: It has been reported in up to $67 \%$ of patients. In severe dyspnoea, the drug of choice is morphine, which by reducing the ventilatory response to hypercapnia and hypoxia decreases respiratory effort and the sensation of asphyxia, thereby improving comfort and reducing the symptom severity by between 20 and 30\%,

- Cough: Present in $70-80 \%$ of patients. In cases of severe cough, the drug of choice is morphine ${ }^{15,19}$.

- Anguish-anxiety: It occurs in $43 \%$ of patients. Anxiety secondary to dyspnea, social isolation and fear of the possibility of the situation to worsen and bring about a fatal outcome is likely to be triggered ${ }^{16,20,21}$.

- Delirium: It occurs in $24 \%$ of patients ${ }^{15,19}$. It is characterized by alterations in the level of consciousness and attention, associated with cognitive and perception alterations. Clinically, it is expressed as hyperactive (agitation, hypervigilance and psychomotor activation), hypoactive (apathy, somnolence, decreased attention and alertness) and mixed (alternating agitation and lethargy). Diagnosis is clinical, and treatment, if possible, seeks to correct the triggering causes, which in COVID-19 are generally hypoxemia, acute inflammatory state, fever and liver alterations, in addition to symptom treatment ${ }^{22}$.

Pharmacological and non-pharmacological symptom control is described in table 1.

\section{Palliative sedation in COVID-19}

Palliative sedation can be used as a therapeutic maneuver to decrease consciousness only when one or more severe symptoms are refractory, i.e., they cannot be controlled despite therapeutic efforts within a reasonable time $e^{21,23}$.

In hypoxic patients with disease progression who do not receive intensive treatment and who evolve unfavorably with severe symptoms (often dyspnea, anxiety 
Gaceta Médica de México. 2021;157

Table 1. Control of severe symptoms in COVID-19

\begin{tabular}{|c|c|c|c|c|}
\hline & \multicolumn{3}{|c|}{ Pharmacological strategies } & \multirow{2}{*}{$\begin{array}{l}\text { Non-pharmacological } \\
\text { strategies }\end{array}$} \\
\hline & Drug & Dose & Precautions & \\
\hline \multirow[t]{2}{*}{$\begin{array}{l}\text { Severe } \\
\text { dyspnea }\end{array}$} & Morphine & $\begin{array}{l}\text {-PO: rapid release, } 5 \mathrm{mg} / 4-6 \mathrm{~h} \text {. } \\
\text {-IV/SC: initial dose } 2.5 \mathrm{mg} / 4 \mathrm{~h} \text {. } \\
\text {-Continuous infusion }(\mathrm{SC} / \mathrm{IV}) \text { : } \\
10 \mathrm{mg} / 24 \mathrm{~h} \text { adjusted according } \\
\text { to response. } \\
\text { Rescue with } 10 \% \text { of morphine } \\
\text { total dose in } 24 \mathrm{~h} \text {. }\end{array}$ & $\begin{array}{l}\text {-Watch for neurotoxicity, hallucinations, } \\
\text { intense sedation, myoclonus, } \\
\text { confusion. In this case, reduce the } \\
\text { dose by } 50 \% \text {. } \\
\text {-In case of nausea or vomiting, use } \\
\text { antiemetic. } \\
\text {-Add a laxative (sodium picosulfate, } \\
\text { lactulose o sennosides). } \\
\text {-In case of kidney failure, } \\
\text { calculate } 50 \% \text { of the dose or use } \\
\text { hydromorphone. }\end{array}$ & \multirow[t]{2}{*}{$\begin{array}{l}\text { - Postural measures: } \\
\text { positioning with thorax in } \\
\text { semi-fowler }>30^{\circ} \text {, lateral or } \\
\text { prone decubitus. } \\
\text { - Relaxation techniques and } \\
\text { management of anxiety. }\end{array}$} \\
\hline & Steroids & $\begin{array}{l}\text {-Dexamethasone (IV or SC), } \\
24 \mathrm{mg} / 24 \mathrm{~h} .\end{array}$ & -Continue if prescribed. & \\
\hline \multirow{2}{*}{$\begin{array}{l}\text { Severe } \\
\text { cough }\end{array}$} & Dextromethorphan & -PO: 15-30 mg/6 h. & $-120 \mathrm{mg} /$ day as maximum dose & \multirow{2}{*}{$\begin{array}{l}\text {-Respiratory hygiene. } \\
\text {-Humidify air/oxygen. } \\
\text {-Postural measures. }\end{array}$} \\
\hline & Morphine & $\begin{array}{l}\text {-PO: rapid release } 2.5 \mathrm{mg} / 4-6 \mathrm{~h} \text {. } \\
\text {-IV/SC: initial dose } 1 \mathrm{mg} / 4 \mathrm{~h} .\end{array}$ & $\begin{array}{l}\text {-Patients with uncontrolled cough } \\
\text { or with abundant secretion should } \\
\text { not receive oral, trans-mucous or } \\
\text { sublingual medication. } \\
\text {-Evaluate the use of sodium } \\
\text { cromoglycate, } 10 \text { mg inhaled } \\
4 \text { times/day. }\end{array}$ & \\
\hline \multirow[t]{2}{*}{ Anxiety } & $\begin{array}{l}\text { Benzodiazepines } \\
\text { (short or ultra- } \\
\text { short action) }\end{array}$ & $\begin{array}{l}\text {-Lorazepam (PO/SL/IV/SC), } \\
\text { 0.5-2 mg /6 h (PRN). } \\
\text {-Midazolam (PO/SL/R/IV/SC), } \\
\text { 2.5-5 mg/6 h (PRN). } \\
\text {-Clonazepam (PO), } \\
\text { 0.5-2 mg/6 h (PRN). }\end{array}$ & $\begin{array}{l}\text { - May precipitate delirium } \\
\text { manifestations. } \\
\text { - Should be used with caution } \\
\text { in patients with carbon dioxide } \\
\text { retention. }\end{array}$ & \multirow{2}{*}{$\begin{array}{l}\text {-Deep relaxation, abdominal } \\
\text { breathing, progressive } \\
\text { muscle relaxation, } \\
\text { imagination relaxation and } \\
\text { hypnosis. } \\
\text {-Cognitive techniques for } \\
\text { containment: letting go, } \\
\text { postponing and arresting } \\
\text { thoughts. } \\
\text {-Active listening and psycho- } \\
\text { emotional support. }\end{array}$} \\
\hline & $\begin{array}{l}\text { Neuroleptics with } \\
\text { anxiolytic effect }\end{array}$ & $\begin{array}{l}\text {-Levomepromazine (SC/IV), } \\
7.5 \mathrm{mg} \text { (up to a maximum of } \\
\text { three times). } \\
\text {-Chlorpromazine, } \\
\text { 4-6 mg/8-12 h (PO) or } \\
\text { 8-12 mg/day infusion (IV). }\end{array}$ & $\begin{array}{l}\text { - Escalating is not suggested. } \\
\text { - Useful in case of anxiety and } \\
\text { delirium. }\end{array}$ & \\
\hline \multirow[t]{4}{*}{ Delirium } & Haloperidol & $\begin{array}{l}\text {-PO/SL/IM/IV/SC, 1-5 mg/4-6 h. } \\
\text { Maintenance } 20 \text { mg/day. }\end{array}$ & $\begin{array}{l}\text { - In adults, } 50 \text { mg/day maximum dose. } \\
\text { Monitor QT interval. }\end{array}$ & \multirow{4}{*}{$\begin{array}{l}\text {-Provide a quiet environment, } \\
\text { avoid excessive stimuli such } \\
\text { as extreme temperature, } \\
\text { excessive light, noise. } \\
\text {-Facilitate reorientation in } \\
\text { time, space and personal. }\end{array}$} \\
\hline & Levomepromazine & -IV/SC: $12.5-25$ mg/dose. & \multirow{2}{*}{$\begin{array}{l}\text { - } 300 \text { mg/day maximum dose. } \\
\text { - Second line if sedation is required. } \\
\text { - SC use not recommended since they } \\
\text { are irritant. }\end{array}$} & \\
\hline & Chlorpromazine & -PO/SL/IV: 0.5-1 mg/4-6 h. & & \\
\hline & Benzodiazepines & $\begin{array}{l}\text {-Lorazepam PO/SL/IV/SC, } \\
0.5-2 \mathrm{mg} / 6 \mathrm{~h} .\end{array}$ & $\begin{array}{l}\text { - May exacerbate agitation. } \\
\text { - Monitor continuously. }\end{array}$ & \\
\hline
\end{tabular}

$\mathrm{IM}$ = intramuscular; IV = intravenous; $\mathrm{PRN}=$ as needed: $\mathrm{SC}=$ subcutaneous; $\mathrm{SL}=$ sublingual; $\mathrm{TM}=$ trans-mucous; $\mathrm{PO}=$ oral route; oral route only if available ${ }^{\star}$ Evaluation by specialists is required for their prescription.

and delirium), palliative sedation should be considered as a good clinical practice ${ }^{4,15}$.

For sedation to be considered ethically and legally fair, the following is required:

- Presence of a refractory symptom.

- Interdisciplinary evaluation (for a joint and consensual decision).
- Registration in the medical record.

- Intent to alleviate suffering (therapeutic proportionality with the use of minimum effective doses for the symptom that is desired to be alleviated).

- Obtaining informed consent.

- Adjustment of doses and drug combinations according to the level of consciousness required for 


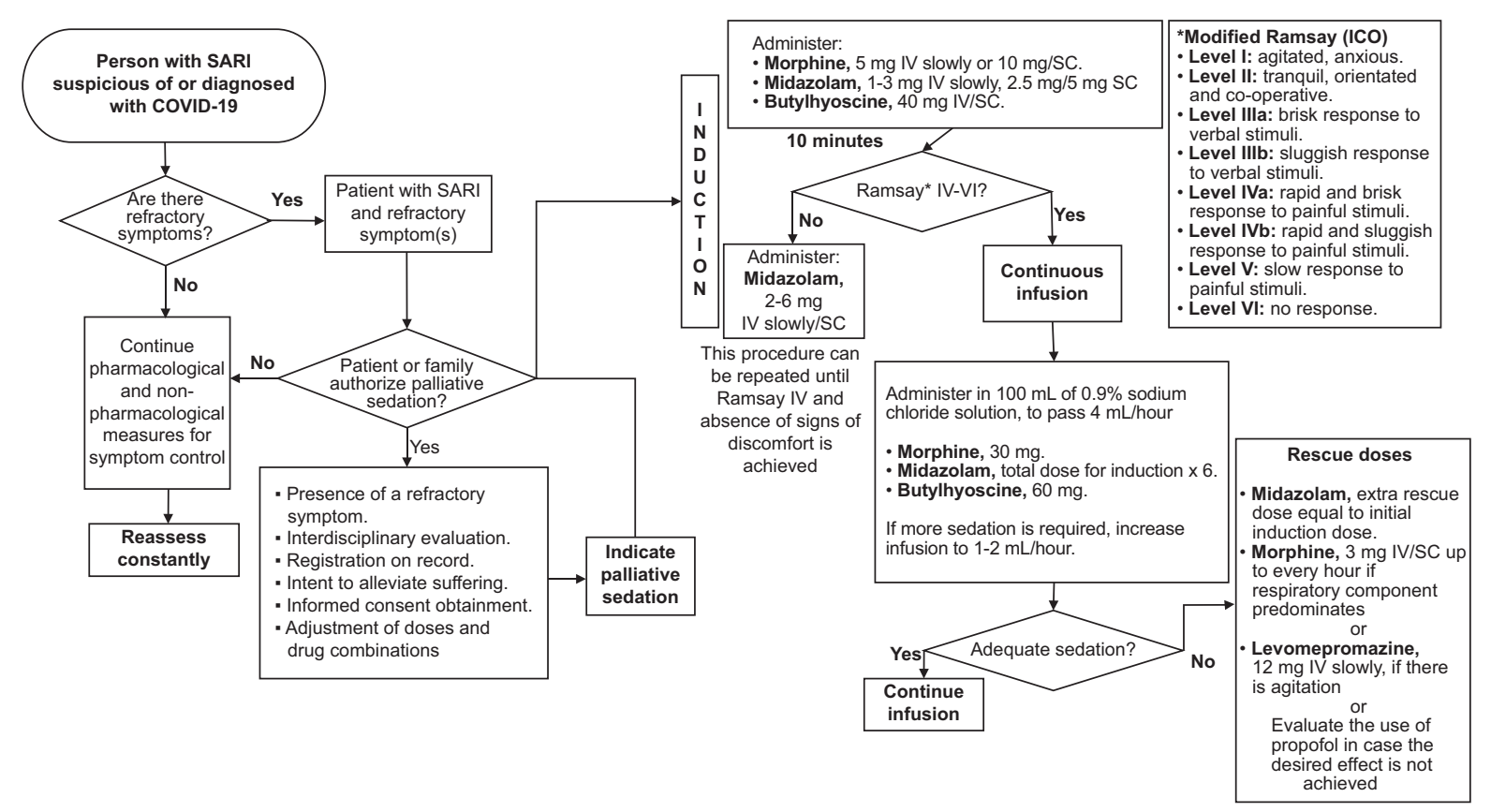

Figure 1. Palliative sedation procedure (adults).

control (preferential use of drugs with rapid metabolism and short half-life).

Palliative sedation should not be confused with euthanasia. Death is a possibility that is secondary to the person's clinical status. If the indication to administer palliative sedation and the applied procedure has been correct, the purpose is to alleviate suffering caused by refractory symptoms and not to cause or accelerate death. A management procedure is proposed in figure $1^{21,23}$.

\section{Palliative management at home}

Some patients decide not to be cared for in a hospital and prefer to stay home. This poses a practical challenge related to the poor development of home care in the country. It entails the challenge of providing trained personnel with adequate personal protective equipment and guaranteeing the prescription of drugs and essential supplies for symptom control ${ }^{24-27}$.

\section{Approach to the person at final stage of life, and death}

In patients who die from COVID-19, the main causes of death are described to be severe acute respiratory distress (ARDS) $(90 \%)$, acute heart failure $(60 \%)$, acute kidney failure $(18 \%)$, shock (12\%) and disseminated intravascular coagulation $(6 \%)^{16}$. Upon entering the final phase of life, it is necessary for therapeutic effort to be adapted, which should be centered on the commitment of non-abandonment and on maintaining relief and comfort, as well as withdrawal of futile drugs or measures lacking significant value for well-being.

During this time, hundreds of thousands of people have died without feeling the affection and closeness of their loved ones. Circumstances make for the adoption of highly strict measures to prevent the transmission of this virus to be imperative; however, we must also reflect on how to facilitate a more compassionate environment in the dying process of these patients, which is part of authentic quality of care ${ }^{28,29}$.

\section{Psychosocial and spiritual care of patients and their families}

Mental health aspects also require dynamic care. Experience in epidemics has shown that absence of an effective mental health and psychosocial support system increases the risks of psychological distress and progression of psychopathologies. The population with the highest risk for experiencing mental health alterations is the most susceptible to complications in case of acquiring the disease (those with comorbidities or older adults), those with preexisting mental health disorders, family members who experience 
Table 2. Comprehensive care of professionals who provide care for COVID-19

Organizational
$\begin{aligned} & \text { 1. Provision of personal protective equipment and supplies to work according to the role in care activities. } \\ & \text { 2. Establishment of protocols for clinical management and use of personal protective equipment in order to act } \\ & \text { with more confidence and less stress. } \\ & \text { 3. Recognition of professionals, emphasizing the great human value their contribution has. } \\ & \text { 4. Generation of strategies for detecting burnout and compassion fatigue. } \\ & \text { 5. Linkage to emotional support groups and virtual or face-to-face psychological care. } \\ & \text { 6. Establishment of a mental health monitoring committee that promotes and supervises established measures. } \\ & \text { 1. Define clear and consistent goals in relation to patient care. } \\ & \text { 2. Encourage positive feedback within the team. } \\ & \text { 3. Have short meetings with the team between crises to discuss and monitor actions and processes. } \\ & \text { 4. Lean on mental health professionals for care. } \\ & \text { 1. Strengthen self-care, comprehensive health management and resilience. } \\ & \text { 2. Share feelings, anxieties, and concerns with trusted people. } \\ & \text { 3. Practice coping with stress with mindfulness or relaxation techniques. } \\ & \text { 4. Take "time out" and foster positive emotions (positive memories). } \\ & \text { 5. Continuous communication with significant people. } \\ & \text { 6. Recognize when help is required and ask for it. }\end{aligned}$

complicated grief and healthcare professionals. Having mental health professionals who approach patients, families and care teams, either face-toface or through communication technologies, is recommended in order to identify emotional distress, accompany and, where appropriate, carry out psychosocial interventions aimed at providing emotional and grieving support ${ }^{30-32}$.

\section{Advanced care, advance directives and do-not-resuscitate orders}

Given the evolution of COVID-19 clinical presentation, it is not always possible to ensure a discussion with the patient and the family about their wishes regarding advanced care in the event of disease progression; however, it should be sought for this discussion to be centered on the person and, ideally, to be early addressed. Advance directives are crucial for avoiding intensive life support management (mechanical ventilation, intensive care and cardiopulmonary resuscitation) when patients do not want it or if it is of no benefit to their quality of life ${ }^{33,34}$. In Mexico, the General Statute of Health grants terminally-ill patients the right to "provide written informed consent for the administration or not of treatments, medications and palliative care appropriate to their illness, needs and quality of life", as well as to "resign, abandon or refuse at any time to receive or continue a treatment he considers to be extraordinary" ${ }^{\prime 34}$.

There are clinical situations in COVID-19 in which a resource should not be used if it is regarded as futile (principle of beneficence), since prolonging the agony of an imminent death could be considered therapeutic obstinacy (non-maleficence) and the benefit should be restricted to other patients with higher possibility of response (justice). In agreement with the family (and if possible with the patient), the treating team can propose an adjustment in therapeutic intensity and direct efforts towards comfort and symptom relief. Given the health emergency, it is important for clear guidelines with an ethical and human rights perspective around the issue to be available. Any discrimination regarding access to healthcare resources due to conditions related to age, disability or any other vulnerability condition should be avoided $28,29,35-39$.

\section{Comprehensive care of professionals who provide care for COVID-19}

Front-line healthcare teams and support areas experience a physical and emotional burden that makes them particularly vulnerable to experiencing physical and mental disorders. It is necessary for strategies that promote comprehensive care, strengthen resilience and detect the need for additional support at the personal, team and organizational level to

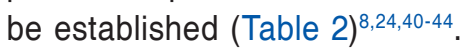

\section{Organization for action}

Various strategies have shown efficacy in other critical scenarios, and can be adapted at the national, institutional or local level to ensure the provision of 
palliative care. Among others, the following can be pointed out $6,41,45$ :

- Optimizing the coordination between the services involved in the care of the individual with COVID-19 in order for direct or distant consultation to be provided to "first-line" professionals in those places where palliative care professionals are available and for personnel to be trained in relation to therapeutic management of symptoms, use of opioids, and psychosocial support bases where such experts are lacking.

- Implementation of palliative care protocols that allow comprehensive care continuity to be preserved with an approach focused on the needs of the patient and his family.

- Availability of personal protective equipment, opioids, and other supplies required for care should be ensured.

- Communication technologies should be incorporated as part of safe response.

- Support of trained volunteer staff.

\section{Conclusion}

Palliative care integration in the healthcare response to the needs of COVID-19 patients and their families is essential. Incorporating the principles of care through symptom control, holistic approach to the needs of the individual, support in decision-making, approach to grief and care of the health team will allow reducing the suffering associated with the disease and improve quality of life, while promoting an efficient use of healthcare resources and the development of a quality health system.

\section{Acknowledgements}

To all health personnel who, with empathy and professionalism, provide care to people with COVID-19. To the PALIATIVISSSTE network for its human commitment.

\section{Conflict of interests}

The authors declare that they have no conflicts of interest.

\section{Funding}

This research has not received any specific grant from agencies of the public, commercial or non-profit sectors.

\section{Ethical disclosures}

Protection of human and animal subjects. The authors declare that no experiments were performed on humans or animals for this research.

Confidentiality of data. The authors declare that no patient data appear in this article.

Right to privacy and informed consent. The authors declare that no patient data appear in this article.

\section{References}

1. Gobierno de México [Internet]. SA/SPPS/DGE/DIE/INDRE/UIES. Informe técnico diario COVID-19 México, 12/10/2021.

2. Redbrick L, Knaul FM, de Lima L, de Jonquiere C, Adelia A. The key role of palliative care in response to the COVID-19 tsunami of suffering. Lancet. 2020;395:1467-9.

3. Canul FM, Farmer PE, Krakauer EL, de Lima L, Baudelio A, Quete XJ, et al. Alleviating the access abyss in palliative care and pain relief an imperative of universal health coverage: the lancet commission report. Lancet. 2018;391:1391-454.

4. Arya A, Buchman S, Gagnon B, Downer J. Pandemic palliative care: beyond ventilators and saving lives. CMAJ. 2020;192:E400-4.

5. Jouvet E, Sevaram M, Besançon K, Krishnaraj G, Hunt M, de Laat S, et al. Palliative care in humanitarian crises: a review of the literature. J Int Hum Action. 2018:3:3-5.

6. Etkind SN, Bone AE, Lovell N, Cripps RL, Harding R, Higginson IJ, et al. The Role and response of palliative care and hospice services in epidemics and pandemics: a rapid review to inform practice during the COVID-19 pandemic. J Pain Symptom Manage. 2020;60:e31-40.

7. World Health Organization. Switzerland: COVID-19 Response: seventy-Third World Health Assembly; 2020.

8. Ting R, Edmonds P, Higginson IJ, Sleeman KE. Palliative care for patients with severe covid-19. BMJ. 2020;370:m2710.

9. Radbruch L, de Lima L, Knaul F, Wenk R, Ali Z, Bhatnaghar S, et al. Redefining palliative care a new consensus-based definition. J Pain Symptom Manage. 202;60:754-64.

10. Bowman BA, Esch AE, Back AL, Marshall N. Crisis symptom management and patient communication protocols are important tools for all clinicians responding to COVID-19. J Pain Symptom Manage. 2020;60:e98-100.

11. Koh MY. Palliative care in the time of COVID-19: reflections from the frontline. J Pain Symptom Manage. 2020;60:e3-4.

12. Janssen DJ, Ekström M, Currow DC, Johnson MJ, Maddocks M, Simonds AK, et al. COVID-19: guidance on palliative care from a European respiratory society international task force. Eur Res J. 2020:56:2002583.

13. Powell VD, Silveira MJ. What should palliative care's response be to the COVID-19 pandemic? J Pain Symptom Manage. 2020;60:e1-3.

14. Fusi-Schdmidhauser T, Preston NJ, Keller N, Gamondi C. Conservative management of Covid-19 patients emergency palliative care in action. J Pain Symptom Manage. 2020;60:e27-30.

15. Bajwah S, Wilcock A, Towers R, Costantini M, Bausewein C, Simon ST, et al. Managing the supportive care needs of those affected by $\mathrm{CO}$ VID-19. Eur Res J. 2020;55:2000815.

16. Keeley P, Buchanan D, Carolan C, Pivodic L, Tavabie S, Noble S. Symptom burden and clinical profile of COVID-19 deaths: a rapid systematic review and evidence summary. BMJ Support Palliat Care. 2020;10:381-4.

17. Schoenherr LA, Cook A, Peck S, Humphreys J, Goto Y, Saks NT, et al. Proactive identification of palliative care needs among patients with $\mathrm{CO}$ VID-19 in the ICU. J Pain Symptom Manage. 2020;60:e17-21.

18. Adams $C$. Goals of care in a pandemic: our experience and recommendations. J Pain Symptom Manage. 2020;60:e15-7.

19. Lovell N, Maddocks M, Etkind SN, Taylor K, Carey I, Vora V, et al. Characteristics, symptom management, and outcomes of 101 patients with COVID-19 referred for hospital palliative care. J Pain Symptom Manage. 2020;60:e77-81.

20. Salins N, Mani RK, Gursahani R, Simha N, Bhatnagar S. Symptom management and supportive care of serious COVID-19 patients and their families in India. Ind J Crit Care Med. 2020:24:435-44

21. Universidad de Navarra. Spain: guías Rápidas de Apoyo y Control Sintomático en Pacientes Avanzados Con COVID-19; 2020.

22. Kotfis K, Marra A, Wesley-Ely E. ICU delirium a diagnostic and therapeutic challenge in the intensive care unit. Anaesthesiol Intensive Ther. 2018;50:160-7. 
23. Arantzamendi M, Belar A, Payne S, Rijpstra M, Preston N, Menten J, et al. Clinical aspects of palliative sedation in prospective studies. A systematic review. J Pain Symptom Manage. 2020;61:831-44.

24. Gilissen J, Pivodic L, Unroe KT, van den-Block L. International COVID-19 palliative care guidance for nursing homes leaves key themes unaddressed. J Pain Symptom Manage. 2020;60:e56-69.

25. Mercadante S, Adile C, Ferrera P, Giuliana F, Terruso L, Piccione T. Palliative care in the time of COVID-19. J Pain Symptom Manage. 2020;60:e79-80.

26. Kuntz JG, Kavalieratos D, Esper GJ, Ogbu N, Mitchell J, Ellis CM. Feasibility and acceptability of inpatient palliative care E-family meetings during COVID-19 pandemic. J Pain Symptom Manage. 2020;60:e28-32.

27. Fausto J, Hirano L, Lam D, Mehta A, Mills B, Owens D, et al. Creating a palliative care inpatient response plan for COVID-19 the UW medicine experience. J Pain Symptom Manage. 2020;60:e21-6.

28. De Montalvo-Jääskeläinen F, Altisent-Trota R, Bellver-Capella V, Cadena-Serrano F, de los Reyes-López M, de la Gándara-del Castillo Á, et al. Informe del Comité de Bioética de España sobre Aspectos Bioéticos de la priorización de recursos en el contexto de la crisis del coronavirus. Pers Bioet. 2020;24:1-13

29. Guía de Criterios Éticos Ante Emergencias Sanitarias en México en el Contexto de la Pandemia por COVID-19. Mexico: Universidad de Anáhuac/Facultad de Bioética; 2020

30. Wallace CL, Wladkowski SP, Gibson A, White P. Grief during the COVID-19 pandemic: considerations for palliative care providers. J Pain Symptom Manage. 2020;60:e70-6.

31. Bakar M, Capano E, Patterson M, McIntyre B, Walsh CJ. The role of palliative care in caring for the families of patients with COVID-19. Am J Hosp Pal Med. 2020;37:866-8.

32. Ferrell BR, Handzo G, Picchi T, Puchalski C, Rosa WE. The urgency of spiritual care: COVID-19 and the critical need for whole-person palliation. J Pain Symptom Manage. 2020;60:e7-11.

33. Petriceks AH, Schwartz AW. Goals of care and COVID-19: a GOOD framework for dealing with uncertainty. Pall Support Care. 2020;18:379-81.

34. Ley General de Salud. Mexico. Diario Oficial de la Federación; 1984.
35. Medina-Arellano M, Palacios-González C, Santos-Preciado Jl. Bioethics guide on scarce medical resource allocation in Mexico. Salud Publica Mex. 2020;62:1-3

36. Wynne KJ, Petrova M, Coghlan R. Dying individuals and suffering populations: applying a population-level bioethics lens to palliative care in humanitarian contexts: before, during and after the COVID-19 pandemic. J Medical Ethics. 2020;46:1-12.

37. Rubio O, Estella A, Cabre L, Saralegui-Reta I, Martin MC, Zapata L, et al. Ethical recommendations for a difficult decision-making in intensive care units due to the exceptional situation of crisis by the COVID-19 pandemia: a rapid review and consensus of experts. Med Intensiva (Engl Ed). 20201:44:439-5.

38. World Health Organization. Switzerland: orientación Ética Sobre Cuestiones Planteadas Por la Pandemia del Nuevo Coronavirus (COVID-19). Geneva: World Health Organization; 2020.

39. Toma de Decisión Para Hospitalización o Cuidados Intensivos de Personas Mayores en el Contexto de la Pandemia de COVID-19. Mexico: Instituto Nacional de Geriatría/Comisión Nacional de Bioétca; 2020.

40. Fadul N, Elsayem AF, Bruera E. Integration of palliative care into COVID-19 pandemic planning. BMJ Sup Pall Care. 2021;11:40-4.

41. Feder SL, Akgün KM, Schulman-Green D. Palliative care strategies offer guidance to clinicians and comfort for COVID-19 patient and families. Heart Lung. 2020;49:227-8.

42. Shaukat N, Ali DM, Razzak J. Physical and mental health impacts of COVID-19 on healthcare workers: a scoping review. Int J Emer Med. 2020;13:40.

43. Cabarkapa S, Nadjidai SE, Murgier J, Ng CH. The psychological impact of COVID-19 and other viral epidemics on frontline healthcare workers and ways to address it: a rapid systematic review. Brain Behav Immun Health. 2020;8:100144.

44. Heath C, Sommerfield A, von Ungern-Sternberg BS. Resilience strategies to manage psychological distress among healthcare workers during the COVID-19 pandemic: a narrative review. Anaesthesia. 2020;75:1364-71.

45. Knights D, Knights F, Lawrie I. Upside down solutions: palliative care and COVID-19. BMJ Support Palliat Care. 2020;2020:bmjspcare-2020-002385. 